\title{
ÉLITES QUITEÑAS Y MECENAZGO PICTÓRICO DURANTE EL BARROCO: LAS SERIES DE LA VIDA DE SAN Agustín y DE LOS EJERCICIOS ESPIRITUALES
}

\author{
QUiteÑO ELITES AND PICTORIAL PATRONAGE \\ DURING THE BAROQUE: THE SERIES OF \\ the Life of Saint Augustine and the \\ SPIRITUAL EXERCISES
}

Ángel Justo Estebaranz

Universidad de Sevilla

RESUMEN: Entre las series pictóricas del barroco quiteño, destacan dos sufragadas por múltiples miembros de las élites locales. Aunque existen otros testimonios de esta práctica en Quito, las series de la vida de san Agustín y de los ejercicios espirituales sobresalen por su conservación y por incluir información relevante sobre sus comitentes, lo que ayuda a esclarecer el impacto que tuvieron en la sociedad quiteña y a fecharlas. En este trabajo estudiamos a los comitentes, indagando en su condición social, y la importancia que el contacto de los pintores con los personajes que costearon las pinturas tuvo en sus futuras carreras.

Palabras clave: élites, mecenazgo, Quito, barroco, pintura

ABSTRACT: Among the pictorial series of the Quito Baroque, two stand out funded by multiple members of the local elites. Although there are other testimonies of this practice in Quito, the series of the Life of Saint 
Augustine and the Spiritual Exercises distinguish for their conservation and for including relevant information about their patrons, which helps to clarify the impact they had on Quito's society and their datation. In this paper we study the patrons, investigating their social status, and the importance that the painters' contact with the people who funded the paintings had in their future careers.

Keywords: elites, patronage, Quito, baroque, painting

\section{INTRODUCCIÓN}

Durante el barroco, los más importantes obradores pictóricos de Quito realizaron series destinadas a ornamentar los cenobios de las órdenes religiosas establecidas en la capital de esta Real Audiencia del Virreinato del Perú. Entre los conjuntos pictóricos conservados en la ciudad, destacan aquellos que representaban la vida de los santos fundadores de cada orden. Generalmente, son series constituidas por numerosas pinturas. La que ha merecido más atención por parte de los investigadores sobre arte quiteño es la serie de la Vida de san Agustín. Este conjunto, obra del pintor quiteño Miguel de Santiago y su taller, fue objeto de estudio ya a comienzos del siglo xx por parte del padre Agustín Iglesias (1909), al que siguieron los aportes de Víctor Puig (1933), José Gabriel Navarro, el padre Enrique Terán (1950) y el padre Vargas (1970), a los que se sumaba la publicación póstuma de Navarro dedicada a la pintura quiteña (1991). ${ }^{1}$ Si se interesaron por las fuentes grabadas, también lo hicieron, hasta cierto punto, por el comitente y los responsables de costear las pinturas, pero en este caso de modo muy resumido, citando apenas los nombres y posición de estos personajes. En 2008 apareció una monografía sobre la serie en la que se estudiaban estilísticamente las obras, sus fuentes grabadas y se abordaban también las circunstancias de su encargo, atendiendo a comitente y donantes. ${ }^{2}$

Por lo que respecta a la serie de los ejercicios espirituales realizada por Francisco Albán para la Casa de Ejercicios de los jesuitas en Quito, su estudio ha merecido el interés de diversos autores desde hace varias décadas. Entre los primeros autores que se interesaron por el conjunto destaca el padre Vargas a comienzos de los años sesenta. En época reciente, han sido Pacheco Bustillos, los jesuitas Cavanna y Chong y Ortiz Crespo quienes han prestado

1. Véase Valentín Iglesias: Miguel de Santiago y los cuadros de san Agustín, Imprenta del Clero, Quito, 1909; Víctor Puig: Un capítulo más sobre Miguel de Santiago, Editorial Gutenberg, Quito, 1933; Enrique Terán: Guía explicativa de la Pinacoteca de Cuadros Artísticos y Coloniales del Convento de San Agustín, precedida de las Biografías del P. Basilio de Ribera y Miguel de Santiago, Imprenta Bona Spes, San Agustín, Quito, 1950; José María VArgas: Miguel de Santiago. Su vida, su obra, Editorial Santo Domingo, Quito, 1970; y José Gabriel Navarro: La pintura en el Ecuador del XVI al XIX, Dinediciones, Quito, 1991.

2. Ángel Justo Estebaranz: Miguel de Santiago en San Agustín de Quito, FOnSAL, Quito, 2008. 
mayor atención a las pinturas. Cavanna y Chong se acercan al conjunto como muestra de la utilización de imágenes con fines evangelizadores, devocionales y formativos presente en los ejercicios espirituales de San Ignacio. ${ }^{3}$ A ambos autores, en cambio, no les interesan los comitentes de esta, ya que ni siquiera aparecen nombrados. Sí lo hacía años antes el padre Vargas, quien señalaba que fueron los mismos ejercitantes quienes se encargaron de sufragar estos lienzos. ${ }^{4}$ Por su parte, y más recientemente, Pacheco Bustillos incidía en que el coste de los cuadros fue asumido por miembros distinguidos de la iglesia y del laicado, planteando que ellos serían quienes se beneficiaron espiritualmente de la orientación de los jesuitas durante los ejercicios. ${ }^{5}$ Ortiz Crespo señalaba que el afán de figuración de los donantes hizo que sus nombres aparecieran en amplias cartelas en el centro de cada pintura. ${ }^{6}$

Estas dos series son representativas de una práctica que se dio en Quito durante el barroco, y que tuvo otros episodios que presentaremos en este trabajo. Ambas poseen elementos en común, tanto en lo referente a la procedencia de los comitentes como a las futuras relaciones que sus pintores entablarían con miembros de las élites quiteñas, que les proporcionarían futuros encargos.

\section{La Vida de SAN Agustín}

La serie más grande pintada en Quito durante la época barroca fue la Vida de san Agustín, encargada por los agustinos de Quito a Miguel de Santiago y destinada a las galerías del claustro bajo del convento. El conjunto fue un encargo del provincial de los agustinos de Quito, fray Basilio de Ribera, y se terminó en 1656, según se indica en la inscripción alojada en la cartela inferior central del cuadro de la Dedicatoria. Como la serie está dedicada al presidente de la Real Audiencia, y este tomó posesión en noviembre de 1655, es posible que la serie se comenzase en esa época y se acabase al año siguiente, o bien que se hubiera empezado antes -dada su amplitud-y que se dedicase al nuevo presidente una vez que este accedió al cargo, coincidiendo con su presencia en Quito en las fechas de su conclusión. En origen, la serie constaba de más de sesenta pinturas que representaban los hechos más notables de la vida de san Agustín, así como

3. Juan Cavanna y Sammy Chong: «Experiencia estética, experiencia transformativa. Un acercamiento a los ejercicios espirituales de San Ignacio desde la colección de cuadros "De Augsburgo a Quito"», en Almerindo E. Ojeda y Alfonso Ortiz Crespo (eds.): De Augsburgo a Quito: Fuentes grabadas del arte jesuita quiteño del siglo XVIII, Fundación Iglesia de la Compañía de Jesús, Quito, 2015, p. 110.

4. José María VArgas: Historia de la Iglesia en el Ecuador durante el patronato español, Editorial «Santo Domingo», Quito, 1962, p. 396.

5. Adriana Pacheco Bustillos: «Los ejercicios espirituales de san Ignacio de Loyola, 1760-64», en Suzanne L. Stratton-Pruit (ed.): The Art of Painting in Colonial Quito, Saint Joseph's University Press, Philadelphia, 2012, p. 182.

6. Alfonso Ortiz Crespo: «Las obras de arte de la antigua recoleta mercedaria de El Tejar», en MAría Antonieta Vásquez Hahn y Alfonso Ortiz Crespo: Historia y arte en El Tejar de la Merced, FONSAL, Quito, 2010, p. 144. 
diversos milagros y apariciones del santo y otros relativos a varios miembros de la orden, como Santa Mónica, Santa Verónica de Binasco y Santo Tomás de Villanueva. Miguel de Santiago contó con la colaboración de sus oficiales Bernabé Lobato, Simón de Valenzuela y Bernabé Carreño -que firmó el lienzo San Agustín enseña retórica-, así como con el agustino fray Alonso Vera de la Cruz -autor de la pintura del Arcángel Uriel a las puertas del Paraíso-.

Fray Basilio de Ribera ideó un plan exitoso para poder llevar a cabo tan grande empeño. Siendo él quien encargó la serie, la financiación de las pinturas corrió a cargo de múltiples devotos del santo residentes en Quito, como hizo constar en la cartela central sujetada por dos ángeles del cuadro de la Dedicatoria, que da comienzo a la serie (Fig. 1). ${ }^{7}$ Contó con una nutrida representación de personajes de la élite quiteña, tanto civil como religiosa y, como cabría suponer, de miembros de la orden agustina. La compensación que encontraron estos donantes - «religiosos y devotos de la religión», como recalca la inscripción- fue que se consignase su nombre y posición en las inscripciones situadas al pie del lienzo que habían pagado, así como su blasón nobiliario en caso de poseerlo. Entre los donantes hubo personas de diferente procedencia, aunque todos de acomodada posición económica. Casi una veintena de ellos-aquellos que poseían blasón nobiliario- hicieron representar su escudo familiar en el lienzo. Entre ellos, funcionarios de la Real Audiencia, como el presidente doctor Pedro Vázquez de Velasco, ${ }^{8}$ y los oidores Luis José Mello de la Fuente y Juan de Morales Aramburo; destacados miembros de la Iglesia, como el ilustrísimo señor Alonso de la Peña Montenegro, obispo de Quito, los canónigos doctores José de Borja, Fernando de Loma Portocarrero (chantre de la catedral, comisario general de la Santa Cruzada) y Francisco de Velasco y Zúñiga (tesorero de la catedral); ${ }^{9}$ el cura y vicario de Tumbaco, Antonio de la Ossa Falconí, comisario del Santo Oficio y Cruzada, ${ }^{10}$ y el licenciado don Ventura Falconí, cura y vicario

7. La inscripción es la siguiente: «ESTA PRODIGIOSA Y ESCLARECIDA HISTORIA DE LA VIDA Y MILAGROS DE LA CATÓLICA LUZ DE LA IGLESIA, NUESTRO GRAN PADRE SAN AGUSTín, MANDÓ PINTAR NUESTRO MUY REVERENDO PADRE FRAY BASILIO DE RIBERA, SIENDO PROVINCIAL DE ESTA PROVINCIA, DE LIMOSNAS DE RELIGIOSOS Y DEVOTOS DE LA RELIGIÓN. Y PARA SU MAYOR LUCIMIENTO Y GLORIA ACCIDENTAL DE SU PATRIARCA, LA DEDICA Y CONSAGRA SU PATERNIDAD MUY REVERENDA AL MUY ILUSTRE Y MAGNÍFICO SEÑOR doctor don Pedro Vázquez de Velasco, del consejo de su majestad, dignísimo presidente de

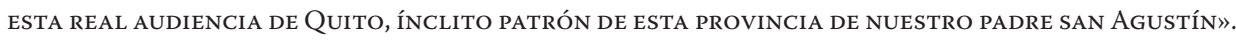

8. Vázquez de Velasco fue promovido después a la presidencia de Charcas. Véase Antonio de Alcedo: Diccionario geográfico-histórico de las Indias Occidentales ó América, Tomo 4, Imprenta de Manuel González, Madrid, 1788, p. 386.

9. Según Rodríguez Docampo, este clérigo era natural de Popayán, criollo, hijo del gobernador Pedro de Velasco y Zúñiga y de Leonor de Cabrera, nieto de Sebastián de Benalcázar. Su desempeño como canónigo estaba de acuerdo «a su calidad, estado y Prebenda, sin haber dado nota en contrario de su persona». Véase Pilar Ponce LeIva: Relaciones histórico-geográficas de la Audiencia de Quito (siglos XVI-XIX), Tomo II (s. XVII-XIX), CSIC, Madrid, 1992, p. 235.

10. Una década después de la conclusión de la serie, el cura doctrinero de Tumbaco comparecía ante la audiencia en un caso relativo a un indio del Cuzco que llegó en calidad de mensajero que proclamaba la venida del Inca, y que portaba una imagen mariana que utilizaba para pedir limosna y que manipulaba de forma no autorizada. Por ello, lo detuvo, le quitó la imagen mariana, en madera policromada y dorada, e hizo que lo azotaran. Véase CARLOS ESPINOSA FERnÁNDEZ DE Córdova: El Inca barroco: política y estética en la Real Audiencia de Quito, 1630-1680, flacso Ecuador, Quito, 2015, pp. 169-170. 
de Riobamba, comisario de la Santa Cruzada e Inquisición; y otros personajes como Francisco Ponce Castillejo, ${ }^{11}$ el capitán Vicente Álvarez Botello, el corregidor Gabriel de Avendaño y Zúñiga y el contador y juez oficial real de la ciudad Antonio de la Chica Cevallos, ${ }^{12}$ el mercader don Pedro Montero de la Calle ${ }^{13}$ y doña Leonor de Saavedra y Monroy, el doctor Pedro Jiménez de Uclés y el comisario del Santo Oficio don Francisco Serrano Monleo. ${ }^{14}$ También figura un escudo en la Visión de santa Verónica de Binasco y san Paulino de Nola, que costeó un canónigo de la catedral de Quito de quien ya en 1950 se había perdido su nombre en la inscripción, como reconoce Terán. ${ }^{15}$

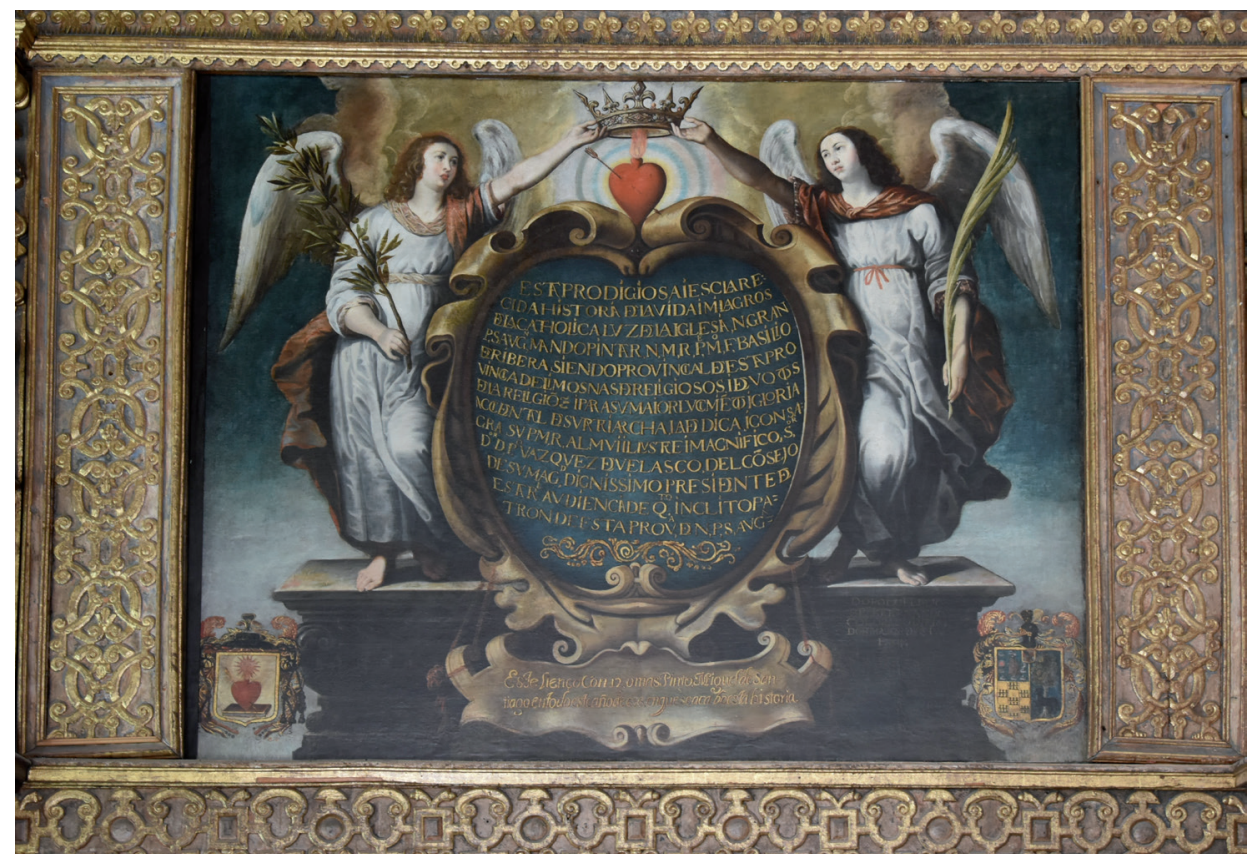

Fig. 1. Miguel de Santiago: Dedicatoria, 1656, serie de la vida de san Agustín, convento de San Agustín, Quito

11. Francisco Ponce Castillejo, criollo, fue regidor de Quito entre 1638 y 1649. Véase PiLAR PONCE LeIvA: Certezas ante la incertidumbre. Élite y Cabildo de Quito en el siglo xvii, Abya-Yala, Quito, 1998, p. 444.

12. Este era hacendado, obrajero y arrendador de obrajes, había sido previamente contador de la Real Hacienda, como Agustín Mesa y Ayala, a quien se le llegó a acusar de ser un hombre de paja de Chica Cevallos. Véase PIlar Ponce LeIva: «Acusaciones de corrupción y prácticas sociales infamantes. Quince años en la vida de Agustín Mesa y Ayala (1670-1685), contador de la Real Hacienda de Quito», en Revista Complutense de Historia de América, 43, Ediciones Complutense, Madrid, 2017, p. 54.

13. En cambio, Terán indicaba en 1950 que este lienzo carecía de escudo nobiliario. Su estado de conservación, muy deteriorado, impide comprobar si lo tuvo. Véase TerÁn: Guía explicativa de la Pinacoteca, pp. 53-54.

14. Según Vargas, entre los religiosos, solo el padre Pedro de San Nicolás, Definidor de la Provincia, hizo constar su blasón familiar en el lienzo costeado por él. Véase José María VARgas: Historia de la cultura ecuatoriana, Casa de la Cultura Ecuatoriana, Quito, 1965, pp. 167-168. No obstante, el cuadro cuyo coste sufragó este religioso -La ordenación de San Agustín- carece de escudo.

15. Terán: Guía explicativa de la Pinacoteca, pp. 36-37. 
Entre los religiosos, era lógico suponer que fueran los agustinos quienes se implicasen directamente en esta gran empresa y, en concreto, los residentes en el convento quiteño. Llama la atención el compromiso de los agustinos de Quito para financiar la serie de pinturas, un total de dieciséis agustinos de Quito, más otros dos de otras ciudades de la Real Audiencia: el reverendo padre fray Antonio Guerrero; ${ }^{16}$ el reverendo padre presentado fray Antonio de la Paz, procurador del convento de Quito; ${ }^{17}$ el hermano fray Pedro Nivela; el reverendo padre maestro fray Agustín Balarezo, regente de estudios del convento quiteño; ${ }^{18}$ el reverendo padre presentado fray Juan Revelo, visitador ordinario de la provincia; el muy reverendo padre fray Agustín de Córdova, provincial de la provincia -que pagó dos cuadros, como el obispo de la Peña Montenegro-; ${ }^{19}$ el muy reverendo padre maestro fray Alonso de Mendoza, definidor mayor de la provincia y presidente del capítulo; el reverendo padre maestro fray Fulgencio de la Serna, el muy reverendo padre maestro fray José Escobar, dos veces provincial de la provincia de Quito; el reverendo padre presentado fray Francisco Viscaíno, visitador ordinario de la provincia de Quito; el padre procurador fray Alonso Sánchez Lobo; el reverendo padre fray Pedro de San Nicolás, definidor de la provincia y prelado superior del convento de Quito; el reverendo padre presentado fray Juan de Larco; el padre fray Juan Daza de Moreta; el padre fray Alonso Toro; fray Joaquín de Sahagún; el tesorero Jaime de Mora Asnar, y el padre prior fray Pedro de Vergara y Enríquez. A ellos se sumaban otros dos agustinos de la Real Audiencia, como el padre presentado fray Lorenzo Suárez de Ocampo, prior del convento de Cuenca, y el reverendo padre fray Jacinto Vallejo, procurador del convento de Latacunga. A todo este número de agustinos habría que añadir la intervención de fray Alonso Vera de la Cruz, también religioso en el convento de Quito, quien no pagó una pintura, sino que pintó trece, colaborando en la serie con Miguel de Santiago y sus oficiales y haciendo constar su nombre en el lienzo que representa al arcángel Uriel con la espada de fuego. ${ }^{20}$ Precisamente, el dorado de la pintura de Uriel fue costeado por el reverendo padre Pedro de la Cruz, procurador de Callo, obraje mayor, tal como hizo constar en una inscripción. ${ }^{21}$ Además de los agustinos, figuraban entre los comitentes otros eclesiásticos: el obispo don

16. En enero de 1635 se había despachado patente para lector de teología a este padre. Véase PIEDAD Costales y Alfredo Costales: Los agustinos, pedagogos y misioneros del pueblo (1573-1869), Ediciones Abya-Yala, Quito, 2003, p. 63.

17. En 1643, fray Antonio de la Paz, fray Juan Rebelo y fray Basilio de Ribera habían optado a los grados de bachiller y licenciado en Teología en la Universidad de San Fulgencio. Véase Costales y Costales: Los agustinos, p. 65.

18. Este se convertiría años después en provincial, como se indica en un poder que da a Sebastián Pérez Navarrete en 1669. Véase Archivo Nacional del Ecuador (ANE), sección Protocolos Notariales, 1 . $^{\text {a }}$ notaría, vol. 222, fol. 241 r-v. Concretamente, en el Capítulo Provincial de julio de 1665 fue electo prior provincial. Véase Costales y Costales: Los agustinos, p. 71.

19. Según Costales, este religioso fue rector de la Universidad de San Fulgencio en 1636-1637. Véase Costales y Costales: Los agustinos, p. 76.

20. La inscripción es la siguiente: «ESTE CHERUbín CO[N] LA ESPADA DE FUEGo A LA PUERTA DEL PARAÍSO DE ESTE CO[N]v[ENTO], Dio Y PINTO POR SU CUENTA CON OTROS DOZE Lie[N]ZOS EL P F Alonso».

21. Según Terán, Callo fue un convento o propiedad de los agustinos en la Provincia de Cotopaxi. Véase Terán: Guía explicativa de la Pinacoteca, p. 48. 
Alonso de la Peña Montenegro y varios curas seculares. Estos eran don Fernando Serrano Monleo, comisario del Santo Oficio y cura y vicario de Conocoto; el doctor don José de Borja, racionero; don Antonio de la Ossa Falconí, cura y vicario de Tumbaco, comisario del Santo Oficio y Cruzada; don Fernando de Loma Portocarrero, chantre de la catedral y comisario general de la Santa Cruzada; el doctor don Francisco de Velasco y Zúñiga, tesorero de la catedral; el licenciado don Ventura Falconí, cura y vicario de Riobamba, comisario de la Santa Cruzada e Inquisición; más otro canónigo que sufragó la Visión de santa Verónica de Binasco y san Paulino de Nola, cuyo nombre es ilegible en la actualidad.

Entre los mercaderes establecidos en Quito, además del mencionado Pedro Montero de la Calle -quien costeó el lienzo Transverberación de san Agustín o San Agustín herido de amor a Cristo-, otros sufragaron el coste de varias pinturas. Así, Lorenzo Romero Marroquín, Francisco Pérez el Toledano, Juan Pérez Infante y Antonio de la Chica Cevallos, todos ellos fiadores al cabildo para la asignación del Cabezón de Alcabala en 1639.22 Otros mercaderes que pagaron lienzos son Francisco de Cáceres, Luis Francisco del Castillo y Duarte Rodríguez - este con el lienzo del Milagro de las ceras, en las que unos devotos devolvían la cera sobrante de unas fiestas a san Agustín en Milán, comprobando el mercader que no había menguado el peso de estas-. Precisamente, fueron dos mercaderes -Juan Pérez Infante y Francisco Pérez el Toledano- quienes hicieron constar expresamente en la inscripción que habían pagado los lienzos «de limosna» - Éxtasis de san Agustín mientras escribe su libro De Trinitate, y Tres milagros de san Agustín, respectivamente-. Son los únicos casos en los que figura esta fórmula, que aparecía de modo genérico en el cuadro de la Dedicatoria-«de limosnas de religiosos y devotos de la religión»-. Pérez Infante era, según Soasti, sevillano avecindado en Quito, y poseía una tienda de mercaderías con un capital de 130.000 pesos que además vendía sal y cacao. ${ }^{23}$ Por su parte, Antonio de la Chica Cevallos había comprado el «empleo de paños» a su padre, Diego de la Chica Narváez, en 1636, y en 1657, un año después de terminada la serie de san Agustín, su padre compraría para él el oficio de escribano público de Cabildo. ${ }^{24}$

También hubo, entre los responsables del pago de los lienzos, algún miembro perteneciente a las órdenes de caballería. Es el caso de José Barnuevo y Alvia, caballero de la Orden de Santiago, que pagó el lienzo de la Muerte de santa Mónica en Ostia. Este personaje procedía de Logroño, y se embarcó para las Indias en $1640 .{ }^{25}$ Llegaría a ser nombrado regidor de la ciudad de Quito en $1668^{26}$ y

22. GuAdalupe SoAsti: «Mercaderes y tratantes en Quito durante el siglo XVII», en Enfoques y estudios históricos. Quito a través de la historia, Dirección y Planificación I. Municipio de Quito/ Consejería de Obras Públicas y Transporte, Junta de Andalucía, Quito, 1992, p. 99.

23. Ibid., p. 93.

24. Ibid., p. 97.

25. Archivo General de Indias (AGI), CONTRATACION, 5423, n. ${ }^{\circ}$ 24, f. 2 v. Barnuevo y Alvia era hijo de Francisco de Barnuevo Cabredo y de Gregoria de Barnuevo, y pasaba a Perú con su criado Juan Gaspar Gener, natural de Mallorca, hijo de Gaspar Gener y de Antonia Pon.

26. Agi, Quito, 213, L. 8, f. 150v-151v. Según Ponce Leiva, ejerció el cargo entre 1665 y después de 1680. Véase Ponce LeIva: Certezas ante la incertidumbre, p. 439. 
tendría larga relación con los agustinos de la ciudad, pues a fines de siglo daba su testimonio a favor de fray Pedro Pacheco, señalando qué obras había realizado en el convento. ${ }^{27}$

Junto a quienes pagaron las pinturas, otros personajes sufragaron el dorado de las molduras. En este caso, cada uno de ellos hizo constar su nombre en una cartela que figura en el lienzo correspondiente, y que debe datar de varios años después. En un documento que estudiamos hace años, pudimos comprobar cómo al menos una parte importante del dorado de los marcos data del provincialato de fray Pedro Pacheco, posterior varios lustros a fray Basilio de Ribera. Ya en un capítulo celebrado en octubre de 1657 se había dado orden de dorar las molduras de los cuadros de la vida de san Agustín y cubiertas del claustro, pues lo ya trabajado era mucho y las maderas corrían riesgo de apolillarse si no se trataban. ${ }^{28}$ Pero aunque se daba orden de disponer de fondos al efecto, debió de ser varios lustros después cuando se llevó a cabo, o al menos cuando se concluyó. Así, en diciembre de 1680, fray Pedro Pacheco hizo testificar a varios personajes para que pusieran de relieve lo que había aportado al convento. Y se menciona expresamente el dorado de las molduras de los cuadros y una restauración de estos. Entre quienes pagaron el dorado de las molduras aparece el sargento mayor don Jorge Lorenzo de Varela, contador mayor de juzgado de bienes de difuntos. El cuadro cuyo marco fue mandado dorar por Varela, que representaba el Nacimiento del santo - una de las escenas importantes en toda serie de santos fundadores- fue durante años considerado como dorado por este personaje. En la inscripción se lee: «Dorolo el Sargento mayor Don Jorge Lorenzo Varela, contador mayor de bienes de difuntos» (fig. 2). Pero Varela no fue el dorador material, sino quien costeó el dorado. Gracias al título que disfrutaba en ese momento, que hizo constar en la cartela, se ha podido fijar la época de dorado del marco entre finales de los años setenta o comienzos de $1680,{ }^{29}$ pues el sargento mayor indicaba que el provincial Pacheco «al presente tiene los dos claustros del d[ic] ho su convento reparados poniendoles sus molduras doradas en todos los liensos». ${ }^{30}$ Otro lienzo, San Agustín entrega su regla, fue dorado por Nicolás de Paz, maestro cerero. Los cereros gozaban en esta época de una holgada situación económica, lo que les permitió sufragar obras de arte como el dorado de estas pinturas. Este cerero llegaría a ser nombrado alcalde del gremio entre los años 1688 y $1692 .{ }^{31}$ También contribuyeron al dorado miembros de la Iglesia, pues el lienzo de la Dedicatoria fue mandado dorar por fray Fernando Colorado, Definidor Mayor de la Provincia de Quito, según consta en la inscripción de la cartela inferior de este lienzo.

27. Ángel Justo Estebaranz: «Fray Pedro Pacheco y su intervención en el convento de San Agustín de Quito», en Tiempos de América, 17, Centro de Investigaciones de América Latina, Universitat Jaume I, Castellón, 2010, pp. 29-30.

28. Archivo Histórico del Convento de San Agustín de Quito (AHSA), vol. 10, fol. $8 \mathrm{v}$

29. Justo Estebaranz: «Fray Pedro Pacheco», p. 31.

30. ANE, P. Q., sección Religiosos, 16-X-1690, fol. 4 r.

31. El nombramiento aparece en Actas del Cabildo Colonial de San Francisco de Quito 1688-1696, Archivo Metropolitano de Historia-Cronista de la Ciudad, Quito, 2012, pp. 8, 57, 86, 114 y 151. 


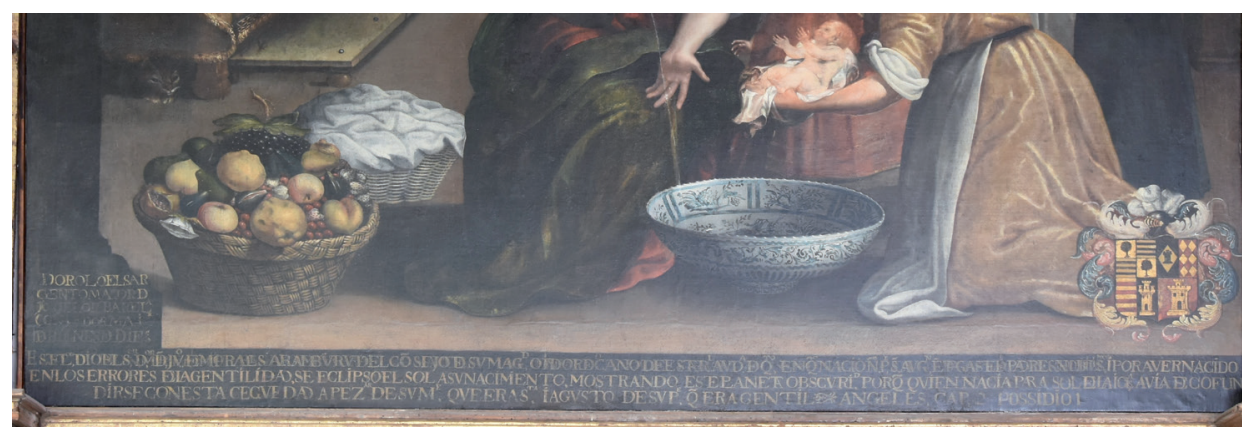

Fig. 2. Miguel De Santiago: detalle de Nacimiento del santo, con las inscripciones de los mecenas de la pintura y del dorado y con el blasón de Juan de Morales Aramburu, 1656, serie de la vida de san Agustín, convento de San Agustín, Quito

Es lógico suponer que, ya que Miguel de Santiago no pudo pintar todos los cuadros, los principales donantes de la serie merecieran la atención del pincel del maestro, mientras que otras pinturas quedaron en manos de sus colaboradores. Esto se cumple en relación a las tres autoridades: fray Basilio de Ribera - provincial de los agustinos y comitente de la serie-, el obispo Alonso de la Peña Montenegro y el presidente de la Audiencia, Don Pedro Vázquez de Velasco -en este caso, la persona a quien estaba dedicada la serie, en el cuadro de la Dedicatoria-. Ellos sufragaron lienzos pintados por Miguel de Santiago, sin la colaboración de discípulos de su taller, a excepción del lienzo de San Agustín y los obispos maldicientes, en el que sí pudieron intervenir, sobre todo en la zona izquierda del cuadro. Estas pinturas, además, se encuentran entre las mejores de la serie. El mismo maestro pintó otros cuadros que representaban escenas relevantes de la vida del santo. Por ejemplo, la Muerte de san Agustín, costeada por el doctor Juan Martín de la Peña. Este doctor aparece relacionado con santa Mariana de Jesús. Es nombrado como «Medico docto, diestro Cirujano, y de muy Christiana conducta», y figura realizando un sangrado a la santa quiteña, según relata Gijón y León. ${ }^{32}$ Morán de Butrón también cuenta este episodio. Y el poeta Jacinto de Evia le dedicó un elogioso soneto con motivo de haber curado al provisor don Antonio de Pinargote. ${ }^{33}$ Juan Martín de la Peña fue médico de la ciudad en 1639, 1645, 1646 y 1667. Era cirujano graduado, y fue nombrado en sustitución de Eugenio Bravo, so-

32. Al practicarle el sangrado, brotó agua y sangre. Véase ThomÁs GiJón y LEón: Compendio histórico de la vida de la venerable sierva de Dios Mariana de Jesús, Flores, y Paredes, conocida con el justo renombre de La Azucena de Quito, Imprenta del Mercurio, por Joseph de Orga, Madrid, 1754, p. 52. Morán de Butrón cuenta cómo, cuando la santa tenía dos o tres años, al pasar por la calle del celebrado doctor Juan Martín de la Peña, este la cogió en brazos y pretendió darle un «ósculo amoroso», pero ella se resistió con los brazos, y el médico empezó a venerarla desde entonces. Véase Jacinto Morán DE Butrón: La Azucena de Quito, Imprenta de Don Gabriel del Barrio, Madrid, s. f., p. 15.

33. JACINTO DE EviA: Ramillete de varias flores poeticas: recogidas y cultivadas en los primeros abriles de sus años, Nicolás de Xamares, Madrid, 1676, p. 79. 
licitando que se le concediese el salario de médico por la cantidad de pobres que requerían de su atención. Asimismo, fue médico y cirujano del Hospital de la Misericordia entre 1646 y $1683 .{ }^{34}$ Este médico, que fue síndico del convento de San Francisco, estaba encargando otras obras importantes en estos mismos años a artesanos indígenas. Por ejemplo, en junio de 1654 firmaba un contrato con el maestro indio Antonio Gualoto para que realizase la pintura y dorado de los retablos de los dos transeptos y de los tres arcos del crucero de San Francisco de Quito, labor por la que cobraría la elevadísima cantidad de 1.900 pesos. ${ }^{35}$ En la orden franciscana, el síndico era un laico, y se encargaba de administrar los recursos de la congregación. ${ }^{36}$ Quizás este médico estuviese relacionado con los posteriores encargos de los franciscanos de Quito a Miguel de Santiago.

Las consecuencias que tuvo este temprano trabajo para la carrera de Miguel de Santiago fueron muy positivas. El nutrido grupo de mecenas constituía una muestra significativa de las élites quiteñas del momento. Eso permitió al pintor darse a conocer tanto entre las élites civiles como religiosas. De los encargos por parte de laicos que pudieron surgir a partir de esta serie no tenemos constancia documental aún, pero sí conservamos pinturas en iglesias quiteñas de factura posterior al conjunto de los agustinos que indican la realización en fechas más avanzadas y que deben de estar relacionadas con el éxito del encargo. Un ejemplo significativo es el del obispo de Quito don Alonso de la Peña Montenegro, que había costeado dos pinturas -San Agustín con los eremitas del monte Pisano y el niño que trataba de vaciar el mar en un hoyo, y San Agustín en la mesa con los obispos maldicientes-. Con posterioridad a la realización de la serie, el prelado encargó el gran lienzo de la Muerte de la Virgen para el altar mayor de la catedral quiteña, pintura que actualmente se

34. Jorge Moreno Egas y Nancy Morán Proaño: Historia del Antiguo Hospital San Juan de Dios. Tomo I. Época colonial: El Hospital de la Misericordia de Nuestro Señor Jesucristo (1565-1830), Instituto Metropolitano de Patrimonio, Museo de la Ciudad, Quito, 2012, pp. 64-65.

35. Ángel Justo Estebaranz y Laura Liliana Vargas Murcia: «Doradores en Santafé (Bogotá) y en Quito en el siglo XVII: artífices, obras y comitentes», en Historia y Sociedad, 35, Universidad Nacional de Colombia (Sede Medellín), Medellín, 2018, pp. 149-150.

36. Según Cruz y Saavedra, el carácter laico del síndico posibilitaba a los religiosos franciscanos dedicar parte del tiempo al estudio y al trabajo manual, a la huerta y a las obligaciones evangélicas y pastorales, lo que les permitía conservar la pobreza y cumplir de esta forma con una de sus reglas - no poseer bienes materiales, sino el usufructo en pago a los servicios que realizaban en cada demarcación territorial-. Por su parte, el síndico afianzaba así su condición social, a la vez que disponía de una posición privilegiada para aumentar su patrimonio y asegurar su salvación eterna. Su nombramiento corría a cuenta de los padres guardianes, y para ello bastaba su linaje, su posición social y el respaldo de su fortuna. El cargo tenía carácter laico o eclesiástico, siendo ajeno a la orden franciscana, y era un puesto apetecible por asegurar el prestigio social y espiritual. Este es un aspecto que debe tenerse en cuenta en una persona, el doctor Juan Martín de la Peña, que tenía fama de buen cristiano. El síndico gastaba los caudales a voluntad del padre guardián, mientras que con las rentas «socorrían a los frailes y a la fábrica conventual», y representaba a los religiosos en sus pleitos, causas y negocios civiles. Véase Antonio CRUz y SaAvedra: «La figura del síndico en la orden franciscana y su papel mediático en el convento de la villa de san Antonio de Gáldar (1520-1836)», en Revista de Historia Canaria, 190, Universidad de La Laguna, San Cristóbal de La Laguna, 2008, pp. 39-40. 
encuentra en el trascoro. Precisamente otro de los comitentes, don José de Borja, que le encargó el lienzo de la Visión de santa Gertrudis, era racionero de la catedral. Asimismo, el doctor don Fernando de Loma Portocarrero, que sufragó la pintura de San Agustín entre la sangre de Cristo y la leche de la Virgen, era el chantre de la catedral. ${ }^{37} \mathrm{Y}$ el doctor don Francisco de Velasco y Zúñiga era el tesorero de la sede quiteña cuando pagó el lienzo San Agustín preside la conferencia de Cartago. Es decir, tanto el prelado de la ciudad como varios canónigos, y entre ellos el encargado de gestionar las cuentas, conocían bien la obra del pintor antes de comisionar el cuadro de la catedral.

Por otra parte, el doctor Juan Martín de la Peña, que le encargó el cuadro de la Muerte de san Agustín, era síndico del convento de San Francisco. A comienzos de los años sesenta, los franciscanos de Quito le encargan las pinturas de la portería del convento, y después la Doctrina cristiana y la Inmaculada eucarística. Quizás fuera el mismo doctor quien apoyase el encargo a Miguel de Santiago y quien firmase el contrato con el pintor, del que no se ha localizado documentación.

Para los propios agustinos, Miguel de Santiago trabajaría en los años posteriores. Ya en el mismo año en que finaliza la serie debía de contar con cierta confianza de los religiosos del convento quiteño, pues aparece como testigo en un poder del convento de San Agustín a fray Juan de Esteisa. ${ }^{38}$ Además de la serie que hemos estudiado, se le encargaría inmediatamente después el gigantesco lienzo de La regla (1656-58), que serviría de magnífico epílogo al trabajo desarrollado en los años inmediatamente anteriores con la Vida de san Agustín. La pintura fue encargada por fray Pedro de San Nicolás -quien había costeado la Ordenación de san Agustín- «siendo vicario Prior de esta Casa el 16 de marzo del año 1656», según consta en la inscripción recogida por Navarro, y se acabaría en 1658, siendo provincial fray Basilio de Ribera. ${ }^{39}$ A este encargo siguieron los lienzos de los Padres de la Iglesia y la Inmaculada..$^{40}$

En esta serie, varios de los donantes de las pinturas tenían relación con el tema que mostraban. Así, el obispo de Quito, que sufragó dos pinturas que

37. Según Ortiz de la Tabla Ducasse citando la relación de Rodríguez Docampo, era hijo del corregidor de Latacunga y tesorero de Quito y nieto del oidor Zorrilla. Véase JAvier OrTiz DE LA TABLA DUCASSE: Los encomenderos de Quito, 1534-1660: origen y evolución de una elite colonial, CSIC, Sevilla, 1993, p. 150. Al momento de escribir su relación Rodríguez Docampo, Loma Portocarrero era criollo, natural de San Marcos de Arica, en el Perú, y este maestrescuela se comportaba con «virtud, mansedumbre y asistencia de su iglesia». La relación está reproducida en PONCE LEIVA, Relaciones histórico-geográficas, p. 234 .

38. El documento data de mayo de 1656, y Miguel de Santiago figura como maestro pintor. También se nombra a un Bernardo Carreño, que podría ser Bernabé Carreño, uno de los colaboradores de Miguel de Santiago. Véase ANE, sección Protocolos Notariales, 3. ${ }^{\circ}$ Notaría, vol. 1, fol. fol. 116 v-117 v.

39. Navarro, La pintura en el Ecuador, p. 71.

40. Véase Ángel Justo Estebaranz: El pintor quiteño Miguel de Santiago (1633-1706). Su vida, su obra y su taller, Secretariado de Publicaciones de la Universidad de Sevilla, Sevilla, 2013, pp. 118-121 y 127-131. 
estaban directamente relacionadas con el episcopado, quiso que constase su blasón precisamente en la que representaba a San Agustín y los obispos maldicientes (fig. 3), en la que se proponía una determinada forma de comportamiento a los prelados. Entre los agustinos del convento quiteño encontramos también ejemplos de esta relación. Por ejemplo, el hermano fray Pedro Nivela pagó el cuadro de la Caridad de san Agustín, relativo a la liberalidad del obispo de Hipona. Y el reverendo padre maestro fray Agustín Balarezo, regente de estudios del convento de Quito, sufragó el lienzo San Agustín y Santo Tomás de Aquino, en el que se indicaba que los devotos de uno y otro santos -entre los que se encontraba él-, «viendo ser su doctrina tan pura y tan santamente verdadera», los representaron cogidos de las manos como columnas de la Iglesia.

La exitosa fórmula ideada por fray Basilio de Ribera fue seguida décadas después por los dominicos de Quito. Concretamente, treinta años después de terminado el conjunto de los agustinos encontramos en Santo Domingo otro, del que se exponen dos pinturas en el Museo Fray Pedro Bedón, que representaba la vida de Santo Domingo. ${ }^{41}$ Siguiendo el ejemplo de esta serie, los cuadros son de gran formato, apaisados, con inscripciones en su parte inferior donde se recogía el nombre y cargo de quien costeó el lienzo. Asimismo, aquellos que tenían blasón nobiliario lo hicieron constar. Aunque se ha relacionado con Francisco Albán, autor del conjunto que abordamos a continuación, estilísticamente no concuerda con su producción, y sí con la de los pintores quiteños de la segunda mitad del siglo XviI. Concretamente, estas pinturas muestran una factura deudora del estilo de Miguel Santiago. Además, los mecenas son de esta época. Por ejemplo, Gaspar de Luna -que pagó el cuadro de la Visión del papa Honorio III-, aparece citado en junio de 1687 en la sentencia contra el teniente general Blas García de la Peña y el maestre de campo Francisco Campuzano.$^{42}$ Curiosamente, cuando más tarde fuera trasladado a un destino menor - «depositado» por decreto de 1690 en la Real Audiencia de Santo Domingo-, Gaspar de Luna pediría no retrasar su viaje alegando su mala salud y la de su mujer, y su pobreza e incapacidad de financiar el viaje ${ }^{43}$ cuando pocos

41. Según el padre Vargas, esta serie se fecha entre 1783 y 1788, y en 1960 aún se conservaban varias pinturas con su firma. Unos años antes, Navarro indicaba que las pinturas colgaban en el claustro inferior del convento dominico, y que un cuadro estaba firmado por Albán en 1798. Véase Adriana PaCHECo Bustillos: «Vida de santo Domingo», en Suzanne L. Stratton-Pruitt (ed.): The Art of Painting in Colonial Quito, Saint Joseph's University Press, Philadelphia, 2012, p. 257.

42. La sentencia está reproducida en María del Pilar Bernal Ruiz: La toma del puerto de Guayaquil en 1687, Escuela de Estudios Hispano-Americanos de Sevilla, Consejo Superior de Investigaciones Científicas, Sevilla, 1979, p. 105. El propio Gaspar de Luna sería recriminado por formar alianzas dentro de la audiencia de la que era oidor y por actuar de acuerdo con ellas, así como por mantener actividades lucrativas y por no respetar el horario del tribunal ni tampoco los términos legales para sentenciar causas. Véase TAMAR HERzOG: Ritos de control, prácticas de negociación: Pesquisas, visitas y residencias y las relaciones entre Quito y Madrid (1650-1750), Fundación Larramendi, Madrid, 2000. https://cutt.ly/de7sX30 consultada el 26 de mayo de 2019 , pp. 58-59.

43. Herzog, Ritos de control, p. 68. 
años antes había podido pagar una pintura de gran formato para los dominicos. Puesto que Gaspar de Luna ejerció el cargo de fiscal entre 1682 y $1687,{ }^{44}$ es en estos años en los que debe fecharse la serie de santo Domingo. Por su parte, el general don Manuel de la Torre Angulo, caballero de la Orden de Santiago y corregidor de Quito, hizo constar su blasón en el lienzo de la Intercesión de la Virgen ante Cristo con san Francisco y santo Domingo. ${ }^{45}$ Como este ejerció su cargo entre diciembre de 1686 y marzo de $1692,{ }^{46}$ es muy probable que la serie de pinturas se realizase en 1687.

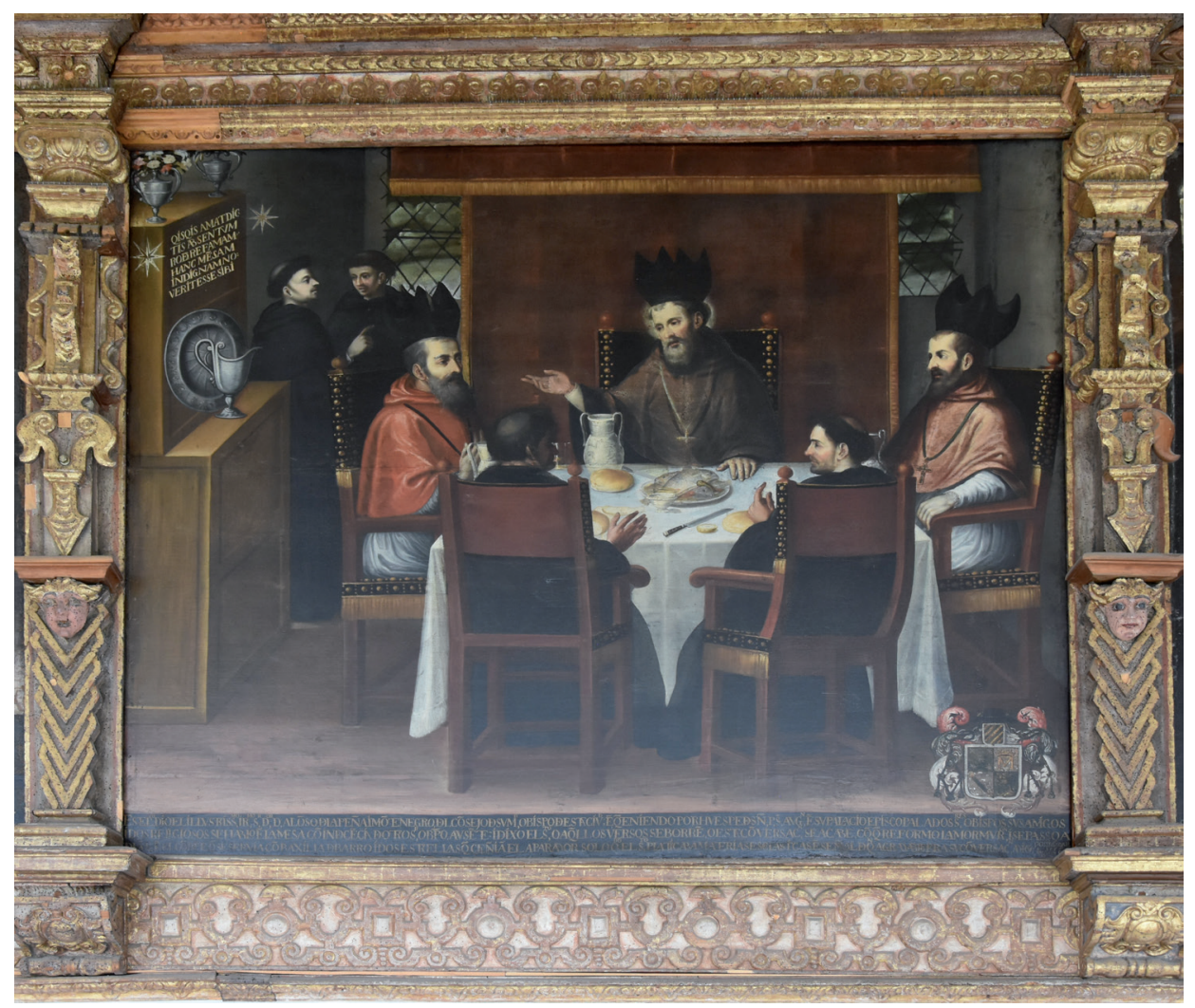

Fig. 3. Miguel de Santiago: San Agustín y los obispos maldicientes, 1656, serie de la vida de san Agustín, convento de San Agustín, Quito

44. Ibid., p. 159.

45. Pacheco Bustillos: «Vida de santo Domingo», p. 257, lo titula Cristo con tres lanzas y san Francisco y santo Domingo como protectores del mundo.

46. El cargo lo había comprado en 1682 por la importante cantidad de 7.000 pesos. Véase ÁNGEL SANZ TAPIA: «Castellanos y leoneses en el gobierno americano bajo Carlos II (1674-1700)», en Naveg@mérica. Revista electrónica editada por la Asociación Española de Americanistas [en línea], Asociación Española de Americanistas, 2016, n. ${ }^{\circ}$ 16, p. 10. http://revistas.um.es/navegamerica. 


\section{LA SERIE DE LOS EJERCICIOS ESPIRITUALES}

Un siglo después de realizada la vida de san Agustín, se encargaba la serie de los ejercicios espirituales para la Casa de Ejercicios de Quito, convertida en noviciado de los jesuitas. A diferencia del anterior conjunto, este constaba de un número significativamente menor de pinturas, en total ocho, realizadas por Francisco Albán entre 1760 y 1764. Aunque no se explicita en ninguna inscripción quién fue el comitente -a diferencia de la serie de los agustinos, en cuya Dedicatoria figuraban comitente y dedicatario-, obviamente debieron de ser los propios jesuitas, concretamente uno de los provinciales o rectores que ejercieron el cargo en esos años. En 1760 -año en que se encargan y entregan las dos primeras pinturas de la serie- el provincial de la provincia quitense era el padre Jerónimo Herze -o Herce-, que ejercía el provincialato desde 1759, y entre 1761 y 1766 ostentó este cargo el padre José Baca, ${ }^{47}$ cuando se completa el conjunto con otros seis lienzos realizados entre 1763 y 1764 . Debieron de ser ellos los responsables primero del encargo, y luego de completar el conjunto. Precisamente, Herce era provincial cuando encargó a Venancio Gandolfi la finalización de la fachada de la iglesia de La Compañía, comenzada en 1722 por Leonardo Deubler y cuyas obras se suspendieron en $1725 .^{48}$

En cuanto a los donantes de los lienzos, que pertenecían tanto a la sociedad civil como a la religiosa, cada uno costeó tanto la pintura como la moldura, según se indica en las cartelas situadas en la zona inferior central de los cuadros. En este sentido, hay una variación respecto a las pinturas de Miguel de Santiago, que fueron sufragadas por donantes a mediados de los años cincuenta, mientras que el dorado corrió a cargo de otros donantes, en tiempos de fray Pedro Pacheco.

Pacheco Bustillos relacionaba esta serie con la decisión del obispo Juan Nieto Polo del Águila de respaldar la construcción en Quito de una casa de ejercicios, dirigida por los jesuitas, en el extremo sur de la ciudad, y cuya fundación se autorizó por real decreto en julio de 1756. Las obras habían comenzado en 1751, construyéndose la capilla en $1753{ }^{49}$ Allí eran divididos los practicantes en grupos de hombres y mujeres y realizaban los ejercicios durante cuatro semanas bajo las indicaciones de los jesuitas. ${ }^{50}$

En los cuadros que componen la serie se representa «el temario que se desarrollaba en las prédicas» ${ }^{51}$ Pero, como en el caso de la vida de san Agustín, el hecho de que se pudiese pagar una pintura de la serie no significaba que el donante de esta tuviera un contacto directo con el conjunto después. La serie de san Agustín se encontraba originalmente en el claustro del convento, y estaba

47. Véase Federico González SuÁRez: Historia general de la República del Ecuador, Tomo v, Imprenta del Clero, Quito, 1894, p. 266.

48. La inscripción donde se recoge la información está reproducida en José Gabriel NavArro: Contribuciones a la historia del arte en el Ecuador, 2. ${ }^{\text {a }}$ edición, TRAMA, Quito, 2007, vol. 4, p. 59.

49. VARgas: Historia de la Iglesia en el Ecuador, p. 382.

50. Pacheco Bustillos: «Los ejercicios espirituales de San Ignacio de Loyola, 1760-64», p. 180.

51. VARgAS: Historia de la Iglesia en el Ecuador, p. 396. 
pensada para los propios religiosos de Quito. Las ocho pinturas encargadas a Albán suponían un apoyo para la composición de lugar que tanta importancia tuvo para los jesuitas en los ejercicios. A través de ellas, se invitaba al ejercitante a crear imágenes mentales, $\mathrm{y}$ han servido como «ayudas en el peregrinar del espíritu de quienes las contemplen». ${ }^{52}$

A pesar de la menor cantidad de pinturas respecto a la serie anterior, su factura se dilató en el tiempo. En las cartelas se indica el nombre de la persona que lo sufragó - todos ellos hombres-, y el año. Las fechas van desde 1760 hasta 1764. El motivo de la extensión en el tiempo no es fácil de desentrañar. En 1760 se pintan dos cuadros, cuatro en 1763 y otros dos en 1764. Parecería más lógico que la serie se pintase entre 1763 y 1764, sin un salto temporal tan grande. No parece deberse a problemas económicos de los jesuitas, ya que no fueron ellos los que pagaron las pinturas. Quizás se planteó la serie en 1760, y no sería hasta tres años después cuando se retomase la actividad para finalizarla. Las dos pinturas más antiguas están relacionadas, pues son una Meditación sobre el fin del hombre y una Meditación sobre la gloria (fig. 4). De esta manera, los ejercitantes contaban con la pintura que da inicio a la serie, que utilizarían en los primeros momentos, y con la que finalizaban los ejercicios. Una vez planteadas estas cuestiones, se pudo completar posteriormente con otros cuadros, llegando a un total de ocho.

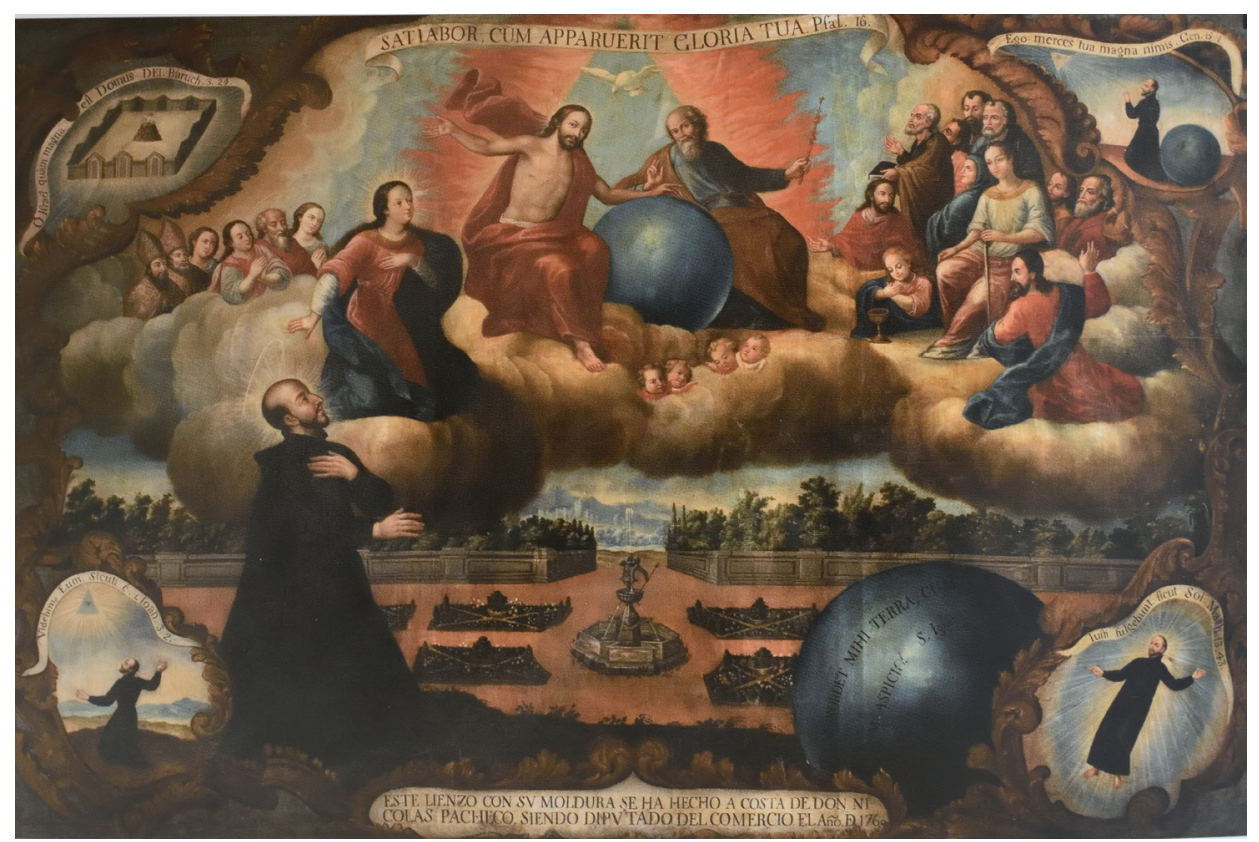

Fig. 4. Francisco Albán: Meditación sobre la gloria, 1760, serie de los ejercicios espirituales, palacio arzobispal, Quito

52. Cavanna y Chong: «Experiencia estética, experiencia transformativa», p. 110. 
Las primeras pinturas de la serie, datadas en 1760, fueron sufragadas por un miembro de las élites religiosas, don Francisco Javier Saldaña (Meditación sobre el fin del hombre $)^{53}$ y, por otro, de las civiles, como don Nicolás Pacheco, cuando era diputado del comercio (Meditación sobre la gloria). Los otros mecenas fueron el doctor don Gregorio Freire (1763, Meditación sobre la penitencia), don Ángel de Izquierdo (1763, Meditación sobre el pecado), don José de Izquierdo (1763, Meditación sobre la muerte), don José de Ascásubi (1763, Meditación sobre la elección entre el bien y el mal), ${ }^{54}$ don Gregorio Álvarez y Verjuste (1764, Meditación sobre el infierno) y don Cayetano Sánchez de Orellana (1764, Meditación sobre el juicio final).

Entre los comitentes de esa serie figuraban varios canónigos de la catedral quiteña. El primero de ellos fue Francisco Javier Saldaña, chantre de la Catedral de Quito. Este clérigo sufragó el primero de los lienzos de la serie. Años después, participó también el doctor don Gregorio Freire, quien costeó un lienzo fechado en 1763 (Fig. 5). Finalmente, en 1764, pagaría el último don Cayetano Sánchez de Orellana. En 1767, este sacerdote recibiría el cargo de canónigo magistral de Quito, dotado de una renta anual de 1.500 pesos, y en esa misma década estuvo a cargo, como provisor y vicario general, de representar los intereses de todos los monasterios de monjas del obispado. ${ }^{55}$ Probablemente, estos sacerdotes pudieron poner en contacto a Albán con el prelado quiteño, don Pedro Ponce Carrasco, quien le encargó un retrato en 1769, conservado en el Museo de América procedente de Huelva, provincia natal del obispo. ${ }^{56}$

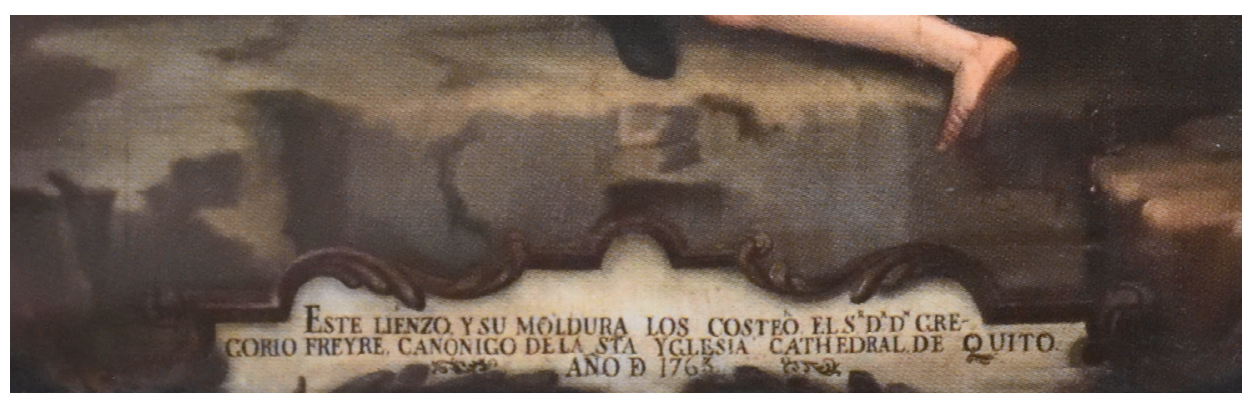

Fig. 5. Francisco Albán: Detalle de la cartela de Meditación sobre la penitencia, 1763, serie de los ejercicios espirituales, palacio arzobispal, Quito

53. Era archidiácono de la catedral, según indica Büschges. Véase CHRISTIAN BüsCHges: Familia, honor y poder. La nobleza de la ciudad de Quito en la época colonial tardía (1765-1822), FONSAL, Quito, 2007, p. 335.

54. Precisamente, el capitán don José Antonio de Ascásubi estaría encargado, tras la expulsión de los jesuitas, del inventario de El Tejar de la parroquia de San Sebastián que ocuparon los jesuitas, tarea que llevó a cabo el 24 de noviembre de 1767. Véase Testimonio del sequestro del Colegio de S. Luys y Universidad de S. Gregorio, fol. 58 r-59 r. https://cutt.ly/Ke7s5CC (consultada el 27 de junio de 2019).

55. BüsChges, Familia, honor y poder, pp. 188 y 194.

56. Ángel Justo Estebaranz: «El retrato del Obispo de Quito Pedro Ponce Carrasco en el Museo de América: Estudio monográfico de la pintura», en Potestas. Revista de Estudios del Mundo Clásico e Historia del Arte, Universitat Jaume I, Castellón, 2017, n. ${ }^{\circ}$ 11, pp. 71-91. 
Junto a estos clérigos, figuraron miembros de la sociedad civil, pertenecientes a las élites quiteñas. Y eso en un momento en que Juan Nieto Polo del Águila, bajo cuyo obispado se había fundado la Casa de Ejercicios jesuita, contribuyó a extender los ejercicios ignacianos a la sociedad laica ${ }^{57}$ Entre ellos, cabe destacar a don José Antonio de Acásubi, natural de Vizcaya y casado en Quito con doña Rosa Mateu y Aranda, hija de los Marqueses de Maenza. ${ }^{58}$ Este personaje se convertiría, por nombramiento del presidente Diguja, en el primer Director de la Junta de Temporalidades. Curiosamente, uno de los ejercitantes que habían costeado pinturas para los jesuitas, pocos años después se encargaba de gestionar los bienes de los religiosos expulsados de Quito.

El orden de realización de las pinturas coincide solo al comienzo con el orden del itinerario de los ejercicios espirituales. Si la Meditación sobre el fin del hombre coincide con una realización temprana (1760), el orden cronológico del resto de pinturas se aleja del propuesto por Cavanna y Chong: El principio y fundamento (Meditación sobre el fin del hombre), La primera semana (Meditación sobre el pecado, Meditación sobre la muerte, Meditación sobre el juicio final, Meditación sobre el infierno, Meditación sobre la penitencia), Meditación de las banderas (Meditación sobre la elección entre el bien y el mal) y Contemplación para alcanzar amor (Meditación sobre la gloria). Hasta ahora no se ha planteado una posible explicación a la razón del orden de estas pinturas. Pero encontramos un claro sentido en el orden del encargo. Las dos primeras pinturas que se pagaron son las correspondientes al comienzo y al final de los ejercicios. Precisamente, la Meditación sobre la gloria, que cierra la serie, es la pintura firmada por Albán. Probablemente, fueran realizadas de forma consecutiva y luego entregadas al mismo tiempo a los jesuitas, que de esta forma contarían con el testimonio de la autoría desde el primer momento.

A estos ocho cuadros que componen la serie sumaba Ortiz Crespo un noveno: La Virgen se aparece a san Ignacio en la cueva de Manresa mientras escribe sus ejercicios espirituales, conservado en el palacio arzobispal. Supone este autor que podría tratarse del primero de la serie, que hubiera pasado también de la Casa de Ejercicios de los jesuitas a la Recoleta de El Tejar, y de esta a la curia, aunque no se conserve documentación que acredite este supuesto. ${ }^{59}$ Por ello, fija su realización hacia 1760. Aunque el formato es diferente, y carece de inscripción, estilísticamente presenta similitudes con los cuadros de Albán. Por ejemplo, son similares el rostro de san Ignacio, los querubines y la corona que porta la Virgen en este y en la Meditación sobre el infierno. Asimismo, el

57. Valeria Coronel Valencia: «Pensamiento político jesuita y el problema de la diferencia colonial», en Alfonso Ortiz Crespo, Sofía Luzuriaga Jaramillo y Adriana Pacheco Bustillos (eds.): Radiografía de la piedra: los jesuitas y su templo en Quito, FONSAL, Quito, 2008, p. 148. Según esta autora, el prelado quiteño había inducido hacia la penitencia al cabildo y a los sacerdotes, así como a los barrios urbanos y parroquias rurales de la circunscripción.

58. González SuÁrez: Historia general, p. 308.

59. Ortiz CRESPO: «Las obras de arte de la antigua recoleta mercedaria de El Tejar», p. 155. 
fondo de paisaje muestra una técnica similar a los que aparecen en varios de los cuadros de la serie.

En cualquier caso, el trabajo para los jesuitas tendría consecuencias positivas para la carrera de Francisco Albán. A diferencia de la serie agustina, no directamente para los jesuitas, pues estos serían expulsados de los territorios hispánicos en 1767, solo tres años después de finalizada la serie. El conjunto pasaría en ese momento a formar parte de las propiedades de la corona española, bajo la jurisdicción de la Junta de Temporalidades. ${ }^{60}$ De ahí pasarían en 1786 a la Casa de Ejercicios mercedaria, valorando cada pintura el mayordomo ecónomo de la casa en 16 pesos. ${ }^{61}$ Finalmente, los cuadros fueron trasladados al palacio arzobispal desde la capilla de San José de El Tejar. ${ }^{62}$ Pero Albán tuvo ocasión de trabajar para otras órdenes una vez expulsados los jesuitas.

Albán consiguió abrirse camino entre la clientela religiosa quiteña y hacerse un nombre en la capital, como dejan claro algunos testimonios de gran relevancia. Concretamente, entre los mismos jesuitas de Quito contamos con la referencia que da el padre Juan de Velasco en su Historia del reino de Quito, escrita a finales del siglo XVIII. Este menciona entre los pintores más importantes de la ciudad a un maestro Albán, nativo de Quito, a quien tuvo la ocasión de conocer, y que probablemente era Francisco. Además, indicaba que los jesuitas habían llevado varias obras de Albán de pequeño formato a Italia, donde se veían con gran admiración, «pareciendo increíble que puedan hacerse en América cosas tan perfectas y delicadas». ${ }^{63}$ Cuando escribe estas palabras, Velasco ha tenido ocasión de ver tanto la serie de la vida de san Francisco Javier, vinculada con el pincel de Albán, como la de los ejercicios espirituales. Al señalar que su obra se mandó a Italia, da a entender la estima que los jesuitas tenían de su trabajo, como muestra de la pintura quiteña que se realizaba en el momento.

\section{Conclusión}

Las series encargadas a Miguel de Santiago y Francisco Albán por agustinos y jesuitas tuvieron un gran impacto en el Quito barroco. En ambos casos, los comitentes consiguieron reunir a una amplia representación procedente de las élites civiles y religiosas de la ciudad, para que asumieran el coste de la pintura y del dorado de las molduras. La contrapartida que obtuvieron fue la perduración de su nombre a través del tiempo merced a las cartelas que figuraban en la zona inferior de los cuadros, así como su rango y, en los casos correspon-

60. Pacheco Bustillos: «Los ejercicios espirituales de San Ignacio de Loyola, 1760-64», p. 182.

61. Ibídem.

62. Ortiz CRESpo: «Las obras de arte de la antigua recoleta mercedaria de El Tejar», p. 143.

63. JuAn de Velasco: Historia del Reino de Quito en la América meridional, Tomo III y Parte III, Imprenta de Gobierno, Quito, 1842, p. 61. 
dientes, su blasón nobiliario en la serie de san Agustín. La fórmula seguida en este conjunto fue bien recibida entre las élites locales, como demuestra la serie sobre la Vida de santo Domingo o, ya en el siglo XVIII, la de los ejercicios espirituales. Ahora bien, la función que tenían estas series era distinta -o más bien, el público objetivo de cada una-. Si la de san Agustín estaba concebida como un modelo de virtud cristiana para los religiosos del convento, la de los jesuitas tenía la misión de servir de ayuda a la meditación no solo de los jesuitas, sino también de los laicos que realizasen los ejercicios espirituales en la casa construida a tal efecto en el sur de Quito. Gracias a las pinturas de Albán, podrían hacerse una correcta composición de lugar. Asimismo, las series estudiadas en este trabajo se diferencian en su situación actual. San Agustín se conserva in situ, decorando las paredes del claustro bajo del cenobio quiteño, mientras que la de los ejercicios espirituales pasó por varias ubicaciones desde la original Casa de Ejercicios hasta el palacio arzobispal. Finalmente, debe destacarse la trascendencia que ambas series tuvieron en la futura actividad de los pintores, pues pusieron a Miguel de Santiago y a Francisco Albán en relación con posibles comitentes, y en disposición de continuar con una fructífera carrera liderando el panorama pictórico quiteño durante los siguientes lustros. Miguel de Santiago encabezaría durante los siguientes cincuenta años el panorama pictórico de Quito. Por su parte, aunque Albán había comenzado su actividad a finales de los años cuarente, fue a partir de ahora cuando tuvo ocasión de acceder a grandes encargos. Entre ellos, la Vida de san Pedro Nolasco, realizada entre 1770 y 1780 y conservada en la antigua recoleta mercedaria de El Tejar, en la que intervendría junto con Casimiro Cortés y Antonio Astudillo, y en varios de cuyos cuadros también se consignó el nombre de los personajes que los financiaron. ${ }^{64}$

\section{Bibliografía}

Actas del Cabildo Colonial de San Francisco de Quito 1688-1696, Archivo Metropolitano de Historia-Cronista de la Ciudad, Quito, 2012.

Alcedo, Antonio de: Diccionario geográfico-histórico de las Indias Occidentales o América, Tomo 4, Imprenta de Manuel González, Madrid, 1788.

Bernal Ruiz, María del Pilar: La toma del puerto de Guayaquil en 1687, Escuela de Estudios Hispano-Americanos de Sevilla, Consejo Superior de Investigaciones Científicas, Sevilla, 1979.

Büschges, Christian: Familia, honor y poder. La nobleza de la ciudad de Quito en la época colonial tardía (1765-1822), FONSAL, Quito, 2007.

64. Por ejemplo, San Pedro Nolasco tomando el hábito de la orden mercedaria, firmado por Albán y fechado en 1770, según recoge Adriana Pacheco Bustillos: «La vida de San Pedro Nolasco», en SuZanne L. Stratton-Pruitt (ed.): The Art of Painting in Colonial Quito, Saint Joseph's University Press, Philadelphia, 2012, p. 214. Navarro fecha la serie entre 1777 y 1780. Véase NAVARro: La pintura en el Ecuador, p. 136. En esta pintura, el nombre del donante figuraba al final de la inscripción inferior, tras la explicación de la escena, a diferencia de las series de San Agustín y de Santo Domingo, en las que cada inscripción comenzaba con el nombre y título o cargo del donante. 
CAVANnA, JuAN y CHONG, SAMmy: «Experiencia estética, experiencia transformativa. Un acercamiento a los Ejercicios Espirituales de San Ignacio desde la colección de cuadros "De Augsburgo a Quito"», en Almerindo E. Ojeda y Alfonso Ortiz, Crespo (eds.): De Augsburgo a Quito: fuentes grabadas del arte jesuita quiteño del siglo XVIII, Fundación Iglesia de la Compañía de Jesús, Quito, 2015, pp. 109-124.

Coronel VAlencia, VAleria: «Pensamiento político jesuita y el problema de la diferencia colonial», en Alfonso Ortiz Crespo, Sofía Luzuriaga Jaramillo y Adriana Pacheco, Bustillos (eds.): Radiografía de la piedra: los jesuitas y su templo en Quito, FONSAL, Quito, 2008, pp. 127-169.

Costales, Piedad y Costales, Alfredo: Los agustinos, pedagogos y misioneros del pueblo (1573-1869), Ediciones Abya-Yala, Quito, 2003.

Cruz y SaAvedra, ANTONio: «La figura del Síndico en la orden franciscana y su papel mediático en el convento de la villa de San Antonio de Gáldar (1520-1836)», en Revista de Historia Canaria, 190, Universidad de La Laguna, San Cristóbal de La Laguna, 2008, pp. 39-68.

Espinosa Fernández de Córdova, CARlos: El Inca barroco: política y estética en la Real Audiencia de Quito, 1630-1680, FLACso Ecuador, Quito, 2015.

EviA, JACINTO DE: Ramillete de varias flores poeticas: recogidas y cultivadas en los primeros abriles de sus años, Nicolás de Xamares, Madrid, 1676.

Gijón y León, Thomás: Compendio histórico de la vida de la Venerable sierva de Dios Mariana de Jesús, Flores, y Paredes, conocida con el justo renombre de La Azucena de Quito, Imprenta del Mercurio, por Joseph de Orga, Madrid, 1754.

GonzÁlez SuÁrez, Federico: Historia general de la República del Ecuador, Tomo v, Imprenta del Clero, Quito, 1894.

Herzog, Tamar: Ritos de control, prácticas de negociación: Pesquisas, visitas y residencias y las relaciones entre Quito y Madrid (1650-1750), Fundación Larramendi, Madrid, 2000 https:// cutt.ly/be7dhSD (consultada el 26 de mayo de 2019).

Iglesias, Valentín: Miguel de Santiago y los cuadros de san Agustín, Imprenta del Clero, Quito, 1909.

Justo Estebaranz, Ángel: Miguel de Santiago en san Agustín de Quito, FONSAL, Quito, 2008.

—: «Fray Pedro Pacheco y su intervención en el convento de San Agustín de Quito», en Tiempos de América, 17, Centro de Investigaciones de América Latina, Universitat Jaume I, Castellón, 2010, pp. 25-35.

-: El pintor quiteño Miguel de Santiago (1633-1706). Su vida, su obra y su taller, Secretariado de Publicaciones de la Universidad de Sevilla, Sevilla, 2013.

—: «El retrato del obispo de Quito Pedro Ponce Carrasco en el Museo de América: Estudio monográfico de la pintura», en Potestas. Revista de Estudios del Mundo Clásico e Historia del Arte, Universitat Jaume I, Castellón, 2017, n. ${ }^{\circ}$ 11, pp. 71-91.

- y Vargas Murcia, Laura Liliana: «Doradores en Santafé (Bogotá) y en Quito en el siglo xvii: artífices, obras y comitentes», en Historia y Sociedad, Universidad Nacional de Colombia (Sede Medellín), Medellín, 2018, n. 35, pp. 139-169.

Morán de Butrón, Jacinto: La Azucena de Quito, Imprenta de Don Gabriel del Barrio, Madrid, s. f.

Moreno Egas Jorge y Morán Proaño Nancy: Historia del Antiguo Hospital San Juan de Dios. Tomo I. Época colonial: El Hospital de la Misericordia de Nuestro Señor Jesucristo (1565-1830), Instituto Metropolitano de Patrimonio, Museo de la Ciudad, Quito, 2012.

Navarro José, Gabriel: La pintura en el Ecuador del XVI al XIX, Dinediciones, Quito, 1991.

-: Contribuciones a la Historia del Arte en el Ecuador, vol. 4, 2. ${ }^{a}$ edición, TRAMA, Quito, 2007.

Ortiz Crespo, Alfonso: «Las obras de arte de la antigua recoleta mercedaria de El Tejar», en María Antonieta Vásquez Hahn y Alfonso Ortiz Crespo: Historia y arte en El Tejar de la Merced, FONSAL, Quito, 2010, pp. 123-176.

Ortiz de la Tabla Ducasse, JAvier: Los encomenderos de Quito, 1534-1660: origen y evolución de una elite colonial, CSIC, Sevilla, 1993. 
Pacheco Bustillos, Adriana: «La vida de san Pedro Nolasco», en Suzanne L. StrattonPruitt (ed.): The Art of Painting in Colonial Quito, Saint Joseph's University Press, Philadelphia, 2012, pp. 214-217.

—: «Los ejercicios espirituales de San Ignacio de Loyola, 1760-64», en Suzanne L. STRATtonPruitt (ed.): The Art of Painting in Colonial Quito, Saint Joseph's University Press, Philadelphia, 2012, pp. 180-187.

-: «Vida de santo Domingo», en Suzanne L. Stratton-Pruitt (ed.): The Art of Painting in Colonial Quito, Saint Joseph's University Press, Philadelphia, 2012, pp. 257-259.

Ponce LeIVA, Pilar: Relaciones histórico-geográficas de la audiencia de Quito (siglos XVI-XIX), Tomo II (s. XVII-XIX), CSIC, Madrid, 1992.

-: Certezas ante la incertidumbre. Élite y Cabildo de Quito en el siglo XVII, Abya-Yala, Quito, 1998.

-: «Acusaciones de corrupción y prácticas sociales infamantes. Quince años en la vida de Agustín Mesa y Ayala (1670-1685), contador de la Real Hacienda de Quito», en Revista Complutense de Historia de América, Ediciones Complutense, Madrid, 2017, n. ${ }^{\circ} 43$, pp. 49-74.

Puig, Víctor: Un capítulo más sobre Miguel de Santiago, Editorial Gutenberg, Quito, 1933.

SANZ TAPIA, ÁngEL: «Castellanos y leoneses en el gobierno americano bajo Carlos II (16741700)», en Naveg@mérica. Revista electrónica editada por la Asociación Española de Americanistas, Asociación Española de Americanistas, 2016, n. ${ }^{\circ}$ 16, pp. 1-22. http://revistas. um.es/navegamerica.

SoAsti, GuAdalupe: «Mercaderes y tratantes en Quito durante el siglo XVII», en Enfoques y estudios históricos. Quito a través de la historia, Dirección y Planificación I. Municipio de Quito/Consejería de Obras Públicas y Transporte, Junta de Andalucía, Quito, 1992, pp. 87106.

Terán, Enrique: Guía explicativa de la Pinacoteca de Cuadros Artísticos y Coloniales del Convento de San Agustín, precedida de las Biografías del P. Basilio de Ribera y Miguel de Santiago, Imprenta Bona Spes. San Agustín, Quito, 1950.

VARgas, José María: Historia de la Iglesia en el Ecuador durante el patronato español, Editorial «Santo Domingo», Quito, 1962.

VArgas, José María: Historia de la cultura ecuatoriana, Casa de la Cultura Ecuatoriana, Quito, 1965.

VArgas, José María: Miguel de Santiago. Su vida, su obra, Editorial Santo Domingo, Quito, 1970.

Velasco, JuAn De: Historia del Reino de Quito en la América meridional, Tomo iII y Parte III, Imprenta de Gobierno, Quito, 1842. 